
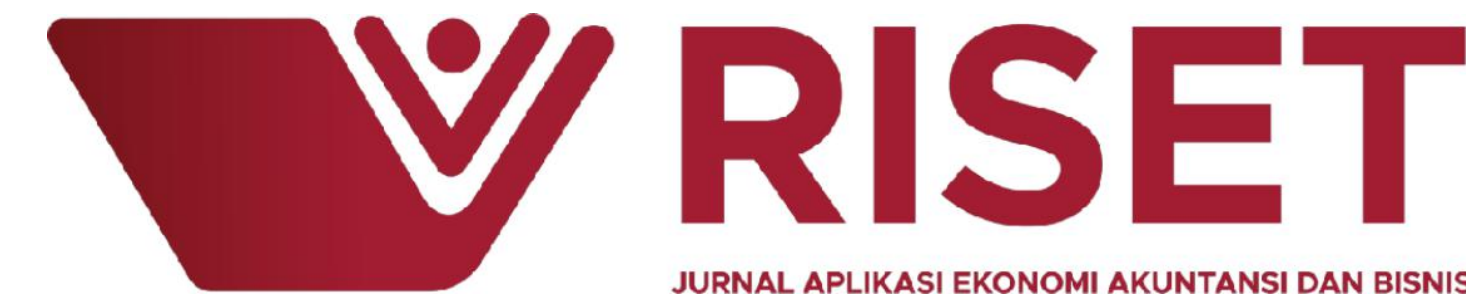

JURNAL APLIKASI EKONOMI AKUNTANSI DAN BISNIS

\begin{abstract}
ANALYSIS OF ACCOUNTING CONSERVATISM AND
BONDHOLDERS-SHAREHOLDERS CONFLICT AGAINST

QUALITY OF PROFIT IN INDONESIA AND AUSTRALIA AND

ITS COMPARISON (Case Studies on Companies Listed on the

Indonesian Stock Exchange and Australian Securities Exchange)
\end{abstract}

Elis Asri Munggaran ${ }_{1)}$, I Gede Sudi Adnyana 2 )

1),2) IBI Kesatuan, Bogor

\begin{abstract}
INFO ARTICLES

Analysis of

Accounting

Conservatism And

Bondholders-

Shareholders

Conflict Against

Quality Of Profit In

Indonesia And

Australia And Its

Comparison

Submitted:

17 - June - 2020

Revised:

13 - September - 2020

Accepted:

25 - September - 2020

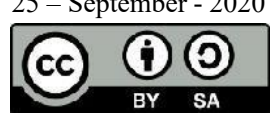

This study aims to determine the effect of accounting conservatism and bondholders-shareholders conflict on the companies' earnings quality that list on the Indonesian Stock Exchange (IDX) and the Australian Securities Exchange (ASX). Besides, this study also aims to determine differences in Indonesia's earning quality level and Australia financial statements. The research method used is a quantitative statistical analysis using the classic assumption test, multiple regression analysis, $\mathrm{T}$-test, and $\mathrm{F}$ test by a significance level of $5 \%$. This study's independent variable $(\mathrm{X})$ is an accounting conservatism and bondholders-shareholders conflict with the dependent variable (Y), earnings quality. The result of the analysis that has been done proves that partially and simultaneously, accounting conservatism has a significant effect on the earning quality in Indonesian and Australian companies.

Meanwhile, in the study of the bondholder-shareholder conflict on earning quality shows that it does not affect achieving quality. But, simultaneously, it involves reaching quality in Indonesian and Australian companies. Meanwhile, based on descriptive statistical analysis, earnings quality in Australia is better than in Indonesia.
\end{abstract}

Keywords: Accounting Conservatism, Bondholders-Shareholders Conflict, Leverage, and Earning Quality

Email: elisasrimunggaran@gmail.com

\title{
INTRODUCTION
}

There are two accounting standards adopted in the world, namely: International Financial Reporting Standards (IFRS) prepared by the International Accounting Standards Board (IASB) and Generally Accepted Accounting Principles (GAAP) composed by the Financial Accounting Standard Board (FASB). The accounting standards adopted by 
Indonesia today is the IFRS International Financial Reporting Standards (IFRS). Also, there are around 120 other countries that have also adopted IFRS, including Australia. The similarity in Indonesia and Australia standards does not cause the financial statements to be presented entirely the same. It is because both of them make relevant accounting standards to apply in their respective countries. Therefore, there will be differences in the financial reporting standards that apply to Indonesia and Australia. The existence of differences in the presentation standards of the financial statements may cause differences in the implementation of the accounting principles adopted in the presentation of financial statements in Indonesia and Australia. One of these accounting principles is the principle of conservatism.

Suwardjono $(2014,245)$ defines conservatism as an attitude or flow (Mazhab) while facing uncertainty to produce a decision based on the emergence of the worst outcome from that uncertainty. According to Wolk et al. (2013), the definition of conservatism is an attempt to select a generally accepted accounting method that results in slower recognition of income, faster recognition of expenses, lower in asset valuation, and higher in the valuation of liabilities. In other words, accounting conservatism can be defined as an act of prudence by an entity or company in presenting financial statements by recognizing accounts that result in a low-profit value to avoid overstating the number of earnings. Kiryanto and Supriyanto (2006) in Alfian (2013) state that financial reports prepared based on the principle of conservatism will tend to be biassed because they cannot describe the real situation.

Conservatism in Indonesia and Australia raised for their choice of recording method for a common condition in the presentation of financial statements, which resulted in the representation. And the value of specific accounts in the financial statements will vary from one company to another company, which ultimately led to earnings tend to be conservative. The high and low value of the company's profits and cash flow will affect the differences in the company's level of earnings quality. It is based on how the earnings quality measurement made by Penman (2010) is where the earnings quality is assessed by comparing operating cash flow with operating income.

Apart from conservatism, the value of the quality of company earnings can also be influenced by bondholders-shareholders conflict. Shareholders who have a role as investors in the company expect the company to have high profits so that their dividends are increased. Simultaneously, bondholders who have the part of creditors or lenders expect profits that are not too high because high profits will increase dividend payment value. The company's reduced net asset value affects the number of debt payments received by the bondholders (Jensen-Meckling, 1976). Based on these descriptions, this study intended to determine whether accounting conservatism and bondholdersshareholders conflict affect the quality of company earnings and how to compare the level of earnings quality of companies in Indonesia and Australia.

\section{Identification of problems}

Based on the background description of the research, the problems discussed in this study are:

1. How does accounting conservatism affect earnings quality in companies that included in LQ45 and ASX50?

2. How does the bondholders-shareholders conflict affect the quality of earnings in companies that included in LQ45 and ASX50?

3. How are the differences in the level of earnings quality in Indonesia and Australia based on the financial statements of companies included in LQ45 and ASX50? 


\section{Research purposes}

This research intended to:

1. To determine the effect of accounting conservatism on earnings quality in companies included in LQ45 and ASX50.

2. To determine the impact of bondholders-shareholders conflict on earnings quality in companies incorporated in LQ45 and ASX50.

3. To resolve differences in the level of earnings quality in Indonesia and Australia based on the financial statements of companies included in LQ45 and ASX50.

\section{LITERATURE REVIEW}

Quality financial information is essential in making economic or investment decisions that can influence interested parties' decisions. In the basic framework for preparing and presenting financial statements, the Institute of Indonesia Chartered Accountants (IAI) states that financial statements' objective is to provide information on the financial position, financial performance, and cash flows of entities. These are useful for most users of financial statements in making economic decisions, which uses financial reports to have a quality financial report. Quality earnings can demonstrate quality financial reports. Low earnings quality can lead to errors in decision making for information users such as investors and creditors so that it will reduce the company's value and the professionalism of accountants. Profits in financial statements can interpret company performance because performance is one of the essential factors that shows the effectiveness and efficiency in achieving its goals. Profit in the current period is used to predict the value of future earnings and the number of future dividends received. Based on the approach made by Penman (2011), earnings quality is measured by comparing the company's operating cash flow with the company's net income. Therefore, the quality of earnings can be affected by the company's value of profits at present. The company's profit value is influenced by the status of applying the company's conservatism principle. The principle of the company's conservatism is applied under IFRS. An example of the company's conservatism in the financial statements is changed in accounting estimates such as understated net assets through hidden reserves, then it will make the net asset value will be too low.

According to the FASB Statement of Concept No.2 Paragraph 95, conservatism is a cautious reaction to uncertainty to ensure that the uncertainties and risks inherent in a business situation are adequately considered. Conservatism is defined as an act of prudence made by the entity or company in preparing the financial statements by recognizing the accounts that resulted in low-profit value to avoid presenting the profit value that overstates. Conservatism will lead to pessimistic financial reporting; this will reduce report users (Ardina \& Januarti, 2012). The purpose of using the concept of conservatism is to neutralize the optimism of entrepreneurs who are too excessive in reporting their business results. The application of the idea of conservatism will result in fluctuating profits, where fluctuating profits will reduce the predictive power of earnings to predict future cash flows (Sari \& Adhariani, 2009). The opposite of conservatism is optimism. The financial statements are said to be optimistic if recognizing changes in value in the accounts contained in the financial statements is following their fair values. Optimism is caused because in evaluating an account, IFRS uses professional judgment. This use of professional appraisal reduces the nature of conservatism and increases the optimism of a financial report.

Also, the conservatism principle's level of application, the company's value of the quality earnings affect by a conflict between bondholders and shareholders. This conflict is called a bondholders-shareholder conflict. Bondholders receive a fixed amount of money from the company (interest on debt), while shareholder income depends on 
the size of the company's profit. In this situation, bondholders pay more attention to the company's ability to repay its debts, and shareholders pay more attention to its ability to obtain considerable returns in investing. Bondholders have the hope that the company's assets will be sufficient when the debt matures asset value determined by the size of the dividend payments made by the company to shareholders. The higher the dividend payment, the less the company's assets will be. The company's dividend payment value level is determined by the high and low value of the company's profits. It will result in a difference of desire in presenting the company's earnings. Shareholders want high profits the dividends received by shareholders large. At the same time, bondholders want low profits that assets used to pay debts to the bondholders sufficient (not substantially diminished due to dividends to shareholders).

\section{METHODOLOGY}

This research is a correlational study intended to analyze the possible influence between the independent variables, namely accounting conservatism, and bondholdersshareholders conflict with the dependent variable, namely earnings quality. Besides, it is also to determine how to compare the level of earnings quality between companies in Indonesia and Australia. This study uses secondary data derived from companies' financial statements in the LQ45 category on the Indonesia Stock Exchange and ASX50 on the Australian Securities Exchange. The financial statements studied are financial statements presented in full for the period 2012 - 2017 with a total of 30 companies. Data analysis performed using descriptive statistical analysis and hypothesis testing with a significance level of 5\%. This study's hypothesis test consists of testing multiple linear regression analysis, the coefficient of determination $\left(\mathrm{R}_{2}\right)$, $\mathrm{t}$-test, and f-test.

The variables in this study were measured by specific methods based on previous research. The dependent variable (Y) in this study, namely the quality of earnings, will be measured using a rate of income ratio based on the Penman approach (2011) with the formula:

$$
K L=\frac{\text { Operational Cashflow }}{\text { Earning Before Interest and Tax }} \times 100 \%
$$

Meanwhile, the first independent variable $\left(\mathrm{X}_{1}\right)$, namely conservatism, will be measured using the operating accrual equation adapted from Zhang's (2007) model, with the following formula:

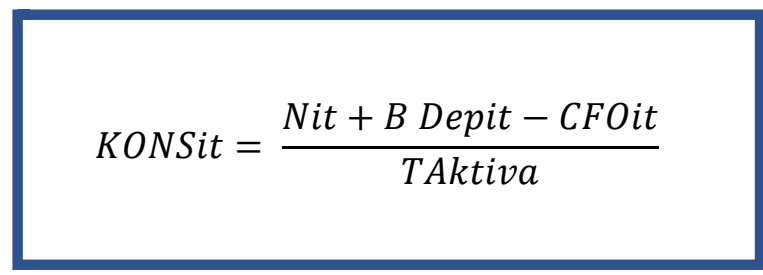
Information
KONSit : Accounting conservatism at companies' $\mathrm{i}$ at time $\mathrm{t}$
Nit : : The company's net profit before extraordinary items
B. Depit $\quad$ : The company's depreciation and amortization expense
CFOit : The company's operating cash flow
T. Assets : Total assets of the company 
The second independent variable $\left(\mathrm{X}_{2}\right)$, namely bondholders-shareholders conflict, is measured using the leverage ratio, namely the debt to total asset ratio (DAR), with the following formula :

$$
\text { Debt Ratio }=\frac{\text { Total Hutang }}{\text { Total Aset }} \times 100 \%
$$

\section{RESEARCH RESULTS AND DISCUSSION}

Descriptive statistics of research variables, which include conservatism, bondholders-shareholders conflict, and earnings quality, can be seen in Table 1 below:

Table 1

Variable Descriptive Statistics

N Minimum Maximum Mean Std. Deviation

\begin{tabular}{|c|c|c|c|c|c|}
\hline Profit Quality & 86 & .167 & 1,993 & 1.02831 & .371765 \\
\hline Conservatism & 86 & -117 & .072 & -.01327 & .035904 \\
\hline The Bondholders-Shareholders Conflict & 86 & .164 & .902 & .48198 & .160008 \\
\hline Valid N (listwise) & 86 & & & & \\
\hline
\end{tabular}

Source: Secondary data processing using SPSS version 25 (2019)

The data obtained, both Indonesian and Australian companies' financial statements, shows that the overall data has a range of earnings quality ratios between $16.7 \%$ to $199.3 \%$. And the average is around $102.82 \%$ and a standard deviation of

$37.17 . \%$. The higher the earnings quality ratio, the better the company's earnings quality. The highest earnings quality ratio is in the financial statements of Australian companies. Meanwhile, the lowest earnings quality ratio is in the financial statements of Indonesian companies.

The average value of conservatism in both countries combined is 0.01327 , meaning that both countries tend to apply to account optimism in delivering financial statements. The conservatism of the average value of both is hostile. When comparing the conservatism value of the two countries, it is known that the average amount of conservatism on the financial statements in Indonesia is smaller than the average conservatism value in Australia. The average amount of conservatism on Indonesia's financial reports is -0.02211 , while the average amount of conservatism on financial reports in Australia is -0.00400 . It means that the presentation of financial statements in Indonesia is more conservative than financial reports in Australia. It is because the lower the conservatism value, the more conservative the company's financial statements are. This comparison can be seen in Table 2 and Table 3 below :

Table 2

Descriptive Statistics of Indonesian Financial Report Data Sample

$\mathrm{N}$ Minimum Maximum Mean Std. Deviation

\begin{tabular}{|l|r|r|r|r|r|}
\hline Indonesian Profit Quality & 44 & .167 & 1,439 & .78550 & .260582 \\
\hline Conservatism & 44 & -117 & .072 & -.02211 & .040128 \\
\hline The Bondholders-Shareholders Conflict & 44 & .164 & .663 & .38227 & .113023 \\
\hline Valid N (listwise) & 44 & & & & \\
\hline
\end{tabular}

Source: Secondary data processing using SPSS version 25 (2019) 
Table 3

Descriptive Statistics Australian Financial Report Data Sample

\begin{tabular}{l|r|r|r|r|r} 
& $\mathrm{N}$ & Minimum & Maximum & Mean & Std. Deviation \\
\hline Australian Earning Quality & 42 & .775 & 1,993 & 1.28269 & .292844 \\
\hline Conservatism & 42 & -.072 & .061 & -.00400 & .028492 \\
\hline The Bondholders-Shareholders Conflict & 42 & .351 & .902 & .58643 & .133554 \\
\hline Valid N (listwise) & 42 & & & & \\
\hline Sourc: Se & & & \\
\hline
\end{tabular}

Source: Secondary data processing using SPSS version 25 (2019)

In the bondholders-shareholders conflict variable, for all data samples in Table 1, it shows that the range of the bondholders-shareholders conflict ratio is in the percentage of $16.4 \%$ to $90.2 \%$. The average was about $48 \%$ and a standard deviation of $16 \%$. If you compare the average value Bondholder-shareholder conflict in both countries' reports on Tables 3 and 4, Indonesia's financial statements have an average cost smaller than the Australian financial statements. The average amount of bondholders-shareholders conflict in Indonesia's financial information is $38.22 \%$, while the average value of bondholders-shareholders conflict on Australia's financial statements is $58.4 \%$. It indicates that companies' performance in Indonesia is $20 \%$ better than the version of companies in Australia when using the data in this study.

The test results of multiple linear regression analysis for Indonesia's companies can be seen in Table 4, which produces the equation $\mathrm{Y}=0.88+5.575 \mathrm{X}_{1}+0.57 \mathrm{X}_{2}$. While the test results of multiple linear regression analysis for companies in Australia can be seen in Table 5, resulting in the equation, $\mathrm{Y}=1.519+7.629 \mathrm{X}_{1}-0.351 \mathrm{X}_{2}$.

Table 4

The simultaneous influence of variables on Indonesian company data

\begin{tabular}{|c|c|c|c|c|c|}
\hline \multirow[b]{2}{*}{ Model } & \multicolumn{2}{|c|}{$\begin{array}{l}\text { Unstandardized } \\
\text { Coefficients }\end{array}$} & \multirow{2}{*}{$\begin{array}{c}\text { Standardized } \\
\text { Coefficients } \\
\text { Beta } \\
\end{array}$} & \multirow[b]{2}{*}{$\mathrm{t}$} & \multirow[b]{2}{*}{ Sig. } \\
\hline & $\mathrm{B}$ & Std. Error & & & \\
\hline 1 (Constant) & .887 & .075 & & 11.901 & .000 \\
\hline Conservatism & 5.575 & .519 & .858 & 10.751 & .000 \\
\hline $\begin{array}{l}\text { Bondholders-Shareholders } \\
\text { Conflict }\end{array}$ & .057 & .184 & .025 & .312 & .757 \\
\hline
\end{tabular}

a. Dependent Variable: Indonesia's Profit Quality

Source: Secondary data processing using SPSS version 25 (2019)

Table 5

The simultaneous effect of variables on Australian firm data

\begin{tabular}{|c|c|c|c|c|c|}
\hline \multirow[b]{2}{*}{ Model } & \multicolumn{2}{|c|}{$\begin{array}{l}\text { Unstandardized } \\
\text { Coefficients }\end{array}$} & \multirow{2}{*}{$\begin{array}{c}\text { Standardized } \\
\text { Coefficients } \\
\text { Beta }\end{array}$} & \multirow[b]{2}{*}{$\mathrm{t}$} & \multirow[b]{2}{*}{ Sig. } \\
\hline & $\mathrm{B}$ & Std. Error & & & \\
\hline 1 (Constant) & .887 & .075 & & 11.901 & .000 \\
\hline Conservatism & 5.575 & .519 & .858 & 10.751 & .000 \\
\hline $\begin{array}{l}\text { Bondholders-Shareholders } \\
\text { Conflict }\end{array}$ & .057 & .184 & .025 & .312 & .757 \\
\hline
\end{tabular}

a. Dependent Variable: Indonesia's Profit Quality

Source: Secondary data processing using SPSS version 25 (2019)

The results from the coefficient of determination $\left(\mathrm{R}_{2}\right)$ in Indonesia's financial statements is around 0.739 . It implies that the effects of both independent variables that accounting conservatism and bondholders-shareholders conflict simultaneously against the dependent variable is the quality of earnings financial reports on companies in Indonesia amounted to $73.9 \%$. Meanwhile, the results of the coefficient of determination $\left(\mathrm{R}_{2}\right)$ in the Australian financial information is 0.525 , which implies that the effects of both independent variables (accounting conservatism and 
bondholders-shareholders conflict) of the dependent variable (the quality of earnings in the financial statements of companies) in Australia amounted to 52.5\%. It can be seen in table 6 and 7 below:

\section{Table 6}

Coefficient of Determination in Companies in Indonesia

\begin{tabular}{lc|rrr} 
Model & $\mathrm{R}$ & R Square & Adjusted R Square & Std. Error of the Estimate \\
\hline 1 & $.860 \mathrm{a}$ & .739 & .726 & .136385 \\
\hline a. Predictors: (Constant), Bondholders-Shareholders Conflict, Conservatism \\
Source: Secondary data processing using SPSS version 25 (2019)
\end{tabular}

Table 7

\section{Coefficient of Determination in Companies in Indonesia}

\begin{tabular}{lr|rrr} 
Model & R & R Square & Adjusted R Square & Std. Error of the Estimate \\
\hline 1 & .725 & .525 & .501 & .206918 \\
\hline
\end{tabular}

a. Predictors: (Constant), Bondholders-Shareholders Conflict, Conservatism Source: Secondary data processing using SPSS version 25 (2019)

F-test used to determine the effect of all the independent variables together - equal to the dependent variable (dependent) and test the digression model's significance. The $\mathrm{F}$ test results in Indonesian corporate data obtained F count $=57.986$ signification level / probable $0.000<0.05$. If seen from the level of significance and the calculated $\mathrm{f}$ value, it concluded that accounting conservatism and bondholders-shareholders conflict have a simultaneous effect on earnings quality in companies' financial statements in Indonesia. It is because the calculated $f$ value is greater than the $\mathrm{f}$ table value (2.84). Meanwhile, Ftest results in the company's data. Australia known that $\mathrm{F}$ count $=21.561$ with a significance level/probability of $0.000<0.05$. When examined from the calculated $\mathrm{f}$ value of 21.561, with a comparison of the f table value, it can be seen that the calculated $f$ value is smaller than the f table value. It means that conservatism and bondholders-shareholders conflict have a combined effect on the quality of earnings on companies' financial statements in Australia. It reflected in table 8 and 9 below:

\section{Table 8}

F test in companies in Indonesia

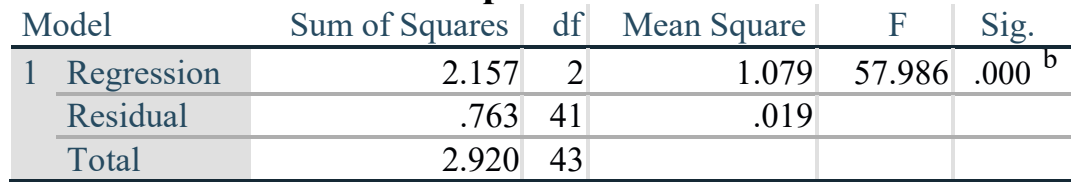

a. Dependent Variable: Indonesia's Profit Quality

b. Predictors: (Constant), Bondholders-Shareholders Conflict, Conservatism Source: Secondary data processing using SPSS version 25 (2019)

Table 9

$F$ test in companies in Indonesia

\begin{tabular}{|c|c|c|c|c|c|}
\hline Model & Sum of Squares & Df & Mean Square & $\mathrm{F}$ & Sig. \\
\hline 1 Regression & 1.846 & 2 & .923 & 21.561 & $.000^{b}$ \\
\hline Residual & 1.670 & 39 & .043 & & \\
\hline Total & 3.516 & 41 & & & \\
\hline
\end{tabular}

a. Dependent Variable: Australian Earning Quality

b. Predictors: (Constant), Bondholders-Shareholders Conflict, Conservatism Source: Secondary data processing using SPSS version 25 (2019) 
The T-test was used to test how the influence of each independent variable (independent) individually on the dependent variable (dependent). As examined in table 10 and 11 , the test result $\mathrm{T}$ performed in the variable accounting conservatism on the quality of corporate profits shows a positive influence. It shows the real (significant) variable conservatism accounting $\left(\mathrm{X}_{1}\right)$ to the variable quality of earnings in the financial statements of companies in Indonesia (Y). In Indonesia's companies, the t value is 10.882, with a significance level of $0.000<0.05$. This value is greater than the table value (1.68288). In an Australian company, the value of $t=6.334$ with 0.000 significance value $<0.05$. The $t$ value at the Australian company is also greater than the $t$ table value (1.68488).

Table 10

T-Test The Effect of Accounting Conservatism on the Quality of Indonesian Companies' Profits

\begin{tabular}{|c|c|c|c|c|c|}
\hline & \multicolumn{2}{|c|}{ Unstandardized Coefficients } & Standardized Coefficients & & \\
\hline Model & B & Std. Error & Beta & $\mathrm{T}$ & Sig. \\
\hline 1 (Constant) & .909 & .023 & & 39.032 & .000 \\
\hline Conservatism & 5.579 & .513 & .859 & 10.882 & .000 \\
\hline
\end{tabular}

a. Dependent Variable: Indonesia's Profit Quality

Source: Secondary data processing using SPSS version 25 (2019)

Table 11

T-Test The Effect of Accounting Conservatism on the Quality of Australian Companies' Profits

\begin{tabular}{|c|c|c|c|c|c|}
\hline & \multicolumn{2}{|c|}{ Unstandardized Coefficients } & \multirow{2}{*}{$\begin{array}{c}\text { Standardized Coefficients } \\
\text { Beta }\end{array}$} & \multirow[b]{2}{*}{$\mathrm{T}$} & \multirow[b]{2}{*}{ Sig. } \\
\hline Model & $\mathrm{B}$ & Std. Error & & & \\
\hline 1 (Constant) & 1.312 & .033 & & 40.177 & .000 \\
\hline Conservatism & 7.273 & 1.148 & .708 & 6.334 & .000 \\
\hline
\end{tabular}

a. Dependent Variable: Australian Earning Quality

Source: Secondary data processing using SPSS version 25 (2019)

Whereas the test $t$ results on the effect of bondholders-shareholders conflict on earnings quality indicate that bondholders-shareholders strife does not affect earnings quality because the significance value of the two data in both countries is more than 0.05 . The $t$ value is smaller than the $t$ table value. The test $t$ results on Indonesian companies show a significance value of $0.749>0.005$, with a value of $t$ count $=0.322$ ( $t$ table value of 1.68288). Meanwhile, the Australian company's t-test results demonstrated a significant amount of $0.996>0.05$, with a $t$ value of 0.005 ( $t$ table value of 1.68488 ). It can be seen in tables $12,13,14$, and 15 .

Table 12

Accounting Conservatism T-Test on Earning Quality Indonesian company

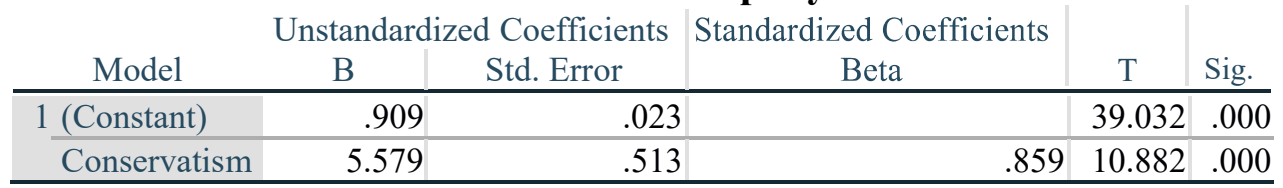

a. Dependent Variable: Indonesia's Profit Quality

Source: Secondary data processing using SPSS version 25 (2019) 
Table 13

T-Test of Accounting Conservatism on Earnings Quality

Australian company

\begin{tabular}{|c|c|c|c|c|c|}
\hline \multirow[b]{2}{*}{ Model } & \multicolumn{2}{|c|}{ Unstandardized Coefficients } & \multirow{2}{*}{$\begin{array}{c}\text { Standardized Coefficients } \\
\text { Beta }\end{array}$} & & \multirow[b]{2}{*}{ Sig. } \\
\hline & $\mathrm{B}$ & Std. Error & & & \\
\hline 1 (Constant) & 1.312 & .033 & & 40.177 & .000 \\
\hline Conservatism & 7.273 & 1.148 & .708 & 6.334 & .000 \\
\hline
\end{tabular}

a. Dependent Variable: Australian Earning Quality

Source: Secondary data processing using SPSS version 25 (2019)

Table 14

T-Test of Bondholder-Shareholder Conflict on Earning Quality Indonesian company

\begin{tabular}{|c|c|c|c|c|c|}
\hline \multirow[b]{2}{*}{ Model } & \multicolumn{2}{|c|}{$\begin{array}{l}\text { Unstandardized } \\
\text { Coefficients }\end{array}$} & \multirow{2}{*}{$\begin{array}{c}\text { Standardized } \\
\text { Coefficients } \\
\text { Beta }\end{array}$} & \multirow[b]{2}{*}{$\mathrm{t}$} & \multirow[b]{2}{*}{ Sig. } \\
\hline & $\mathrm{B}$ & Std. Error & & & \\
\hline 1 (Constant) & .742 & .142 & & 5.242 & .000 \\
\hline $\begin{array}{l}\text { Bondholder-Shareholder } \\
\text { Conflict }\end{array}$ & .114 & .355 & .050 & .322 & .749 \\
\hline
\end{tabular}

a. Dependent Variable: Indonesia's Profit Quality

Source: Secondary data processing using SPSS version 25 (2019)

Table 15

T-Test of Bondholders-Shareholders Conflict on Earning Quality Australian company

\begin{tabular}{|c|c|c|c|c|c|}
\hline \multirow[b]{2}{*}{ Model } & \multicolumn{2}{|c|}{$\begin{array}{l}\text { Unstandardized } \\
\text { Coefficients }\end{array}$} & \multirow{2}{*}{$\begin{array}{c}\text { Standardized } \\
\text { Coefficients } \\
\text { Beta }\end{array}$} & \multirow[b]{2}{*}{$\mathrm{t}$} & \multirow[b]{2}{*}{ Sig. } \\
\hline & $\mathrm{B}$ & Std. Error & & & \\
\hline 1 (Constant) & 1,282 & .208 & & 6,150 & .000 \\
\hline $\begin{array}{l}\text { Bondholders-Shareholders } \\
\text { Conflict }\end{array}$ & .002 & .347 & .001 & .005 & .996 \\
\hline
\end{tabular}

a. Dependent Variable: Australian Earning Quality

Source: Secondary data processing using SPSS version 25 (2019)

Analyzing the quality of earnings at companies in Indonesia and Australia, analyzed through descriptive statistics, may be seen in table 16. In this analysis, the average earnings quality score for Indonesian firms is at 0.78550 , while the average earnings quality score for Australian firms is 1.28269 .

Table 16

\section{Comparison of the Profit Quality Levels of Indonesia and Australia}

\begin{tabular}{lrr|r|r|r|} 
& $\mathrm{N}$ & \multicolumn{1}{c|}{ Minimum } & Maximum & \multicolumn{1}{c}{ Mean } & \multicolumn{1}{c}{ Std. Deviation } \\
\hline Indonesian Profit Quality & 44 & .167 & 1,439 & .78550 & .260582 \\
\hline Australian Earning Quality & 42 & .775 & 1,993 & 1.28269 & .292844 \\
\hline Valid N (listwise) & 42 & & & & \\
\hline
\end{tabular}

Source: Secondary data processing using SPSS version 25 (2019)

\section{DISCUSSION}

In terms of partial (the effect of each variable $\mathrm{X}$ to variable $\mathrm{Y}$ ), be concluded that only conservatism that influence the quality of earnings. At the same time, the bondholders-shareholders conflict does not affect the quality of corporate profits. Based on the test results, accounting conservatism positively affects the quality of earnings by the equation $Y=0.909+5.579$ (see table 12) on Indonesia and $Y=1.312+7.273 \mathrm{X}$ (table 13) on a sample of data in Australia. It means that in the data in Indonesia, if the 
conservatism value is zero, then the earnings quality value is 0.909 , and every addition of 1 conservatism value will cause an increase in the profit value of 5.579. Whereas in Australia's data, if the conservatism value is zero, then the earnings quality value is 1.312 , and every one addition to the conservatism value will cause an increase in the profit value of 7.273 .

In this study, the smaller the conservatism value, the more conservative the company is. So the positive influence in this study means that corporate conservatism is inversely proportional to earnings quality. It means that the more conservative the company is, the lower the company's earnings quality. It shows that the greater the value of the company's accrual earnings than the value of its assets, the higher its earnings quality. Conservatism will lower reported earnings due to unreported reserves, which will reduce the company's profitability and earnings quality. This study's results support research conducted by Rahma Helmi (2015), which states that earnings quality is significantly affected by accounting conservatism. This study's results also strengthen the research conducted by Penman and Zhang (2002), which proves that companies that have a high level of conservatism tend to allocate their reserves to the following years so that profits tend not to be persistent.

Meanwhile, the result of test $t$ on the bondholders-shareholders conflict shows a significance value greater than 0.05 and a calculated $t$ value that is smaller than the table value for both Indonesian and Australian companies. It means that the bondholdersshareholders conflict does not significantly affect the quality of company earnings. The study results support the research conducted by Siti Wulandari (2018), which states that the variables that determine bondholders-shareholders conflict, namely size, and leverage, do not affect earnings quality. It concluded that this study's results indicate that, although the percentage of the number of assets financed by large debts does not reflect that the company has low earnings quality and prospects in the future. The level of leverage does not guarantee that the company has quality profits when viewed from its operating profit size compared to its operating cash flow.

However, when viewed simultaneously, bondholders-shareholders conflict and conservatism have a joint influence on earnings quality. The results of the $f$ test in this study produce the calculated f value in the company data in Indonesia of 57.986 and the estimated f value of the company data in Australia of 21.561, where the second calculated $\mathrm{f}$ value is greater than the $\mathrm{f}$ table value. The research results using the $\mathrm{f}$ test support the research conducted by Eka Pitria (2016), which states that leverage as an indicator of bondholders-shareholders conflict has a significant and positive effect on earnings quality. It means that simultaneously the bondholders-shareholders conflict affects the quality of earnings. It is because, in investing, shareholders will consider the use of corporate debt. After all, it will affect the rate of return that will be received by shareholders. If most of the company's assets are financed by debt, management will improve performance to pay off its debts. Companies with a high level of debt can use their debt to finance the company's operational activities so that the company's possibility of making profits increases with high yields. The option of the company's ability to pay a debt is returns received by shareholders are high. The opportunity of the company to expand the effort was outstanding. So high debt can produce quality company profits.

The comparison of earnings quality in Indonesian and Australian companies are based on descriptive statistical analysis that has been carried out. Based on the study that has been conducted, the value of earnings quality in Australia is higher than in Indonesia. The level of company compliance can influence it by presenting the company's financial statements. Based on previous research conducted by Devi Kharisma Dewantari Kiswara (2015), it shows that Australia is in the top rank in terms 
of compliance with IFRS adoption while Indonesia is ranked sixth. Besides, this can also be influenced by the level of company optimism. In this study, it is known that the average conservatism ratio in Australia is higher than the average conservatism ratio in Indonesia. It means that companies' financial statements in Australia are more optimistic than those of companies in Indonesia. Based on the result, it is known that accounting conservatism has a positive effect on earnings quality. In this study, positive influence is defined as an inversely proportional relationship. It means that the greater the value of conservatism, the more optimistic the company is. Thus, the more promising the company is, the higher the value of the company's earnings quality. It shows that the optimism of financial reports in Australia is higher than the optimism of financial reports in Indonesia, which means that the quality of earnings in Australia is better than Indonesia's quality of earnings.

\section{CONCLUSION AND SUGGESTION}

\section{Conclusion}

Simultaneously, accounting conservatism and bondholders-shareholders conflict affect the quality of company earnings. However, partial, only accounting conservatism that influences the quality of companies' earnings, while bondholders-shareholders conflict does not significantly impact corporate profits. These results indicate that the company's optimism in preparing financial statements can improve the quality of the company's earnings. Simultaneously, the number of assets financed by debt does not reflect that its prospects, as assessed by its earnings quality, are not useful in the future. As for comparing the quality of earnings, the quality of profits on companies' financial statements in Australia is higher than the rate of incomes in financial reports in Indonesia.

\section{Suggestion}

In this study, the indicators used to measure conservatism, bondholdersshareholders conflict, and earnings quality only use one indicator for each variable. For further research, it is hoped that more hands can be used to produce more accurate data analysis results. Besides, due to the limited researchers, the number of sample data used is limited. For further research, it is hoped that more accurate data samples can be used.

\section{REFERENCE}

Asri, Marselinus. 2017. Accounting Conservatism and Earning Quality. Atma Jaya University, Makassar, Indonesia.

Australian Accounting Standard Board. 1997. AAS04 Depreciation. Australian Accounting Research Foundation, Australia.

Basu, Sudipta. 1997. The Conservatism Principle and The Asymmetric Timeliness of Earnings. Journal Of Accounting \& Economics 24 (December): 3-37.

Begley, J., 1994. Restrictive Covenant Included in Public Debt Agreement: An Empirical Investigation. Working Paper, University of British Columbia.

Belkaoui, AR, 2011. Accounting Theory: Accounting Theory, Jakarta: Salemba Empat.

Devi Kharisma Dewanti Kiswara. (,2015). Comparative Study of Adoption Level of Compliance with International Financial Reporting Standards (IFRS) in 12 Countries. Diponegoro University, Semarang.

Deviyanti, Dyahayu Artika. 2012. Analysis of Factors Affecting the Implementation of Conservatism in Accounting (Study of Manufacturing Companies Listed on the Indonesia Stock Exchange). Diponegoro University, Semarang. 
Eka Pitria. 2016. The Effect of Growth Opportunities, Leverage, and Profitability on Earnings Quality. Padang State University.

Financial Accounting Standards Board (FASB). 1980. "Statement of Financial. Accounting Concepts No.2: Qualitative Characteristics of Accounting.

Gaver, JJ, KM Gaver, and JR Austin. 1995. Additional Evidence on Bonus Plan and Income Management. Journal of Accounting and Economics: 19, 328.

Givoly, D., Hayn, C., 2000.The Changing Time-Series Properties of Earnings, Cash Flows, and Accruals: Has Financial Reporting Become More Conservative. Journal of Accounting and Economics 29, 287-320.

Handojo, Irwanto. 2011. A little bit of Accounting Conservatism. STIE Trisakti Journal. Vol: 2, p. 7.

Hans Hananto Andreas, Albert Ardeni, Easter Ika Nugroho. 2017. Accounting Conservatism in Indonesia (April). Vol: 20 No. 1, p. 7.

Harahap, Sofyan Syafri. 2008. Critical Analysis of Financial Statements. PT. Raja Grafindo Persada: Jakarta.

Khairana, Najwa. 2009. Analysis of the Existence of Accounting Conservatism and Factors Affecting the Manufacturing Industry in Indonesia. University of Indonesia, Jakarta.

Lasdi, Lodovicus. (,2008). Determinants of Accounting Conservatism. The 2nd NationalConference UKWMS Surabaya. P 7 - 10, 17 \& 18.

Mahari, Ardhyayuda Patria., Purwanto, Agus. 2016. The Effect of Dividend and Cash Dividend Payment Status on the Quality of Company Profits. Dipenogoro University, Semarang.

Moh. Nasih, Robith Hudaya. 2011. Accounting Conservatism and BondholderShareholder Conflict in Non-Financial Companies Listed on the Indonesia Stock Exchange. Journal of Accounting and Management (December). Vol: 22, No. 3, pp. 193 - 202.

Murwaningsari, Etty. (2008) Several factors affect the Earnings Response Coefficient (ERC). XIth National Accounting Symposium (SNA), Pontianak

Mustikawati, Andrie, and Cahyonowati, Nur. 2015 The Influence of Information Asymmetry on Earnings Management with Firm Size as a Moderating Variable. Dipenogero Journal of Accounting. Vol: 4 No. 4, pg, p. 7.

Novita, Mega. 2017. The Effect of Bondholder-Shareholder Conflict, Bonus Plan, and Political Cost on Accounting Conservatism. PGRI Yogyakarta University, Yogyakarta.

Handojo, Irwanto. 2011. A little bit of Accounting Conservatism. STIE Trisakti Journal. Vol: 2, p. 7.

P, Maria Sinta. 2016. Analysis of Differences in the Level of Accounting Conservatism Before and After IFRS Convergence. Thesis State University of Padang, Padang.

Penman, SH, \& Zhang, X. -J. (,2002). Accounting Conservatism, The Quality of Earnings, and Stock Returns. The Accounting Review, 237-264.

Pika Ramanuningsih. 2012. The Effect of ROA, Leverage, and Growth on Earnings Quality . Sebelas Maret University, Surkarta.

Retnaningtyas, Ariestya. 2016. Measurement and Factors Affecting Accounting Conservatism. Thesis. Airlangga University, Surabaya.

Sari, Cynthia, and Desi Adhariani. 2009. Corporate conservatism in Indonesia and the factors that influence it. SNA XII: Indonesian Accounting Association.

Sari, Dahlia. 2004. The Relationship Between Accounting Conservatism and Bondholders-Shareholders Conflict Regarding Dividend Policy and Bond Rating. Indonesian Journal of Accounting and Finance (December), Vol. 1. 
Scott, WR 2012. Financial Accounting Theory Sixth Edition. USA: Pearson Prentice Hall.

Seswanto, Herbowo. 2012. The Influence of Conservatism on Profit Quality with Accounting Based and Market Based Approaches. University of Indonesia: Depok, West Java.

Smith, C., and J. Warner. 1979, On Financial Contracting: An Analysis of Bond Covenants. Journal of Financial Economics. Vol: 7, 117-161.

Sugiyono. (,2016). Quantitative Research Methods, Qualitative and R \& D. Bandung: PT Alphabet.

Supriyanto, Edi, and Kiryanto. 2006. Effect of Moderation Size on Conservatism Profit Relationship with Conservatism Balance Sheet. Accounting National Symposium IX. Padang.

Suwardjono. 2013. Engineering Accounting Theory and Financial Reporting. BPFEYogyakarta.

Watts, RL, 2003. Conservatism in Accounting Part I: Explanations and Implications. Journal of Accounting and Economics.

Wolk, HI, Dodd, JL, and Rozycki, JJ 2013. Accounting Theory: Conceptual Issues in a Political and Economic Environment. 7th Ed. Thousand Oaks, California: Sage Publications, Inc

Wulandari, Dina Tri. 2014. The Effect of Litigation Risk on Accounting Conservatism Before and After IFRS Convergence in Manufacturing Industry Sectors Listed on the IDX. Essay. Widyatama University: Bandung.

Wulandari, Siti. 2018. The Influence of Profit Growth, Size, Leverage, Investment Opportunity Set, and Good Corporate Governance, on Profit Quality. Essay. Muhammadiyah Surakarta University.

Zelmiyanti, Riri. 2014. Developments in the Application of Conservatism Principles in Accounting. (February): 50 - 55 